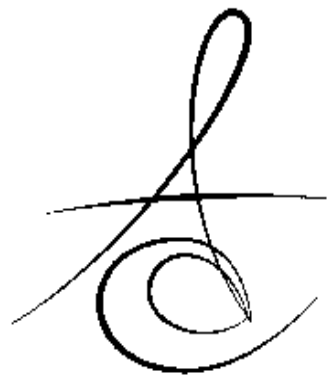

\title{
ÇOCUK DİŞ HEKİMLİĞİNDE KULLANILAN KAVİTE DEZENFEKSİYON YÖNTEMLERİ
}

\section{CAVITY DISINFECTION METHODS USED IN PEDIATRIC DENTISTRY}

\author{
Dr. Öğr. Üyesi İpek ARSLAN* \\ Doç.Dr.özgül BAYGIN ${ }^{* *}$
}

Makale Kodu/Article code: 3058

Makale Gönderilme tarihi: 10.10 .2016

Kabul Tarihi: 15.12.2016

\section{öz}

Son dönemde estetik kaygıların artması neticesinde rezin esaslı materyallerin kullanımının yaygınlaşmasıyla diş dokularının korunmasına yönelik koruyucu kavite preperasyonu teknikleri gündeme gelmiştir. Dentin dokusunun rengine ve sertliğine bakılarak çürüğün uzaklaştırılmasına karar verilen koruyucu yöntemler görsel ve dokunma duyularına dayanması nedeniyle subjektif veriler sunmakta ve diş dokularının içinde yer alan bakterileri uzaklaştırmakta yetersiz kalmaktadır. Dentinin içinde yer alan bu rezidüel bakteriler; enzimatik aktivetelerini sürdürerek sayılarını artırmakta, postoperatif hassasiyet, ikincil çürük ve pulpal enflamasyona sebep olabilmektedirler. Günümüzde bu problemleri önlemek amacıyla kavite dezenfeksiyon yöntemleri önerilmektedir. Bununla birlikte kullanılan kavite dezenfektanlarının antibakteriyel özelliklerine ilaveten; restoratif materyallerin diş sert dokularına bağlanma dayanımına ve mikrosızıntıya etkilerinin de bilinmesi önem taşımaktadır.

Anahtar Kelimeler: Çürük, bakteri, kavite dezenfeksiyonu

\section{ABSTRACT}

Recently, preventive cavity preperation has gained popularity due to widespreading resin based materials for esthetic reasons. Preventive methods which examine tooth color and structure provide subjective data and they are insufficient to eliminate bacterias in dental tissues. These residual bacterias in dentin continue to enzimatic activities and increase the numbers so cause postoperative sensivity, secondary caries and pulpal inflamation. Today, cavity disinfection methods are recommended to avoid these problem. In addition to their antibacterial properties it is also important to know their effects on the bond strength of restorative materials to dental hard tissues and effects on microleakage.

Key words: Dental caries, bacteria, cavity disinfection

\section{GİRIŞ}

Kavite preperasyonu tamamlandıktan sonra enfekte dentin varlığının tayini klinik ortamda genellikle ayna ve sond yardımıyla görsel ve dokunma duyularına dayanarak yapılmaktadır. Bu yöntem; klinik deneyim gerektirmekte, objektif veriler sunmamakta ve bakteriyel durumu yansitmakta oldukça yetersiz kalmaktadır. Araştırmacılar bu nedenlere dayanarak çürük indikatörlerini önermişlerdir ${ }^{1}$.

Enfekte dentin teşhisinde objektif veriler sunan çürük indikatörleri kullanılarak hazırlanan kavitelerin dahi \%15-40'ında bakteri varlığı tespit edilmiştir. Mikroorganizmalar boyanan dentinin kaldırılmasını takiben pulpa yönüne doğru 0.1-2.4 mm uzaklıkta bile görülebilmektedir ${ }^{1-4}$. Dentinin içinde yer alan bu rezidüel bakteriler; enzimatik aktivetelerini sürdürerek sayılarını bir ayda iki katına kadar artırabilmektedirler. Mikroorganizmaların neden olduğu postoperatif hassasiyet, ikincil çürük ve pulpal enflamasyonu önlemek amacıyla kavitelerin dezenfeksiyonu önerilmektedir ${ }^{1-9}$. Günümüzde kavite dezenfeksiyonunda;

- Klorheksidin glukonat (CHX)

- Sodyum hipoklorit ( $\mathrm{NaOCl})$

- Hidrojen peroksit $\left(\mathrm{H}_{2} \mathrm{O}_{2}\right)$

- Benzalkolyum klorür

- İyodin solüsyonları

\footnotetext{
${ }^{*}$ Recep Tayyip Erdoğan Üniversitesi Diş Hekimliği Fakültesi, Pedodonti AD, Rize, Türkiye

${ }^{* *}$ Karadeniz Teknik Üniversitesi Diş Hekimliği Fakültesi, Pedodonti AD, Trabzon, Türkiye
} 
- Fosforik asit

- Fluorid

- Propolis

- Aloe vera

- Ozon

- Işıkla aktive olan dezenfeksiyon sistemleri (Photo-Activated Disinfection-PAD)

- $\quad$ Lazer gibi madde ve yöntemler kullanılmaktadır.

\section{Klorheksidin Glukonat (CHX)}

KlorheKsidin; santral heksametilen halkası ile birleştirilmiş iki 4-korofenil halkası ve iki biguaniz grubundan oluşan katyonik simetrik bir moleküldür. Kimyasal adı 1,1 Hexamethylenebis [5-(4chlorophenyl) biguanide]'dir. Stabil bir yapıya sahiptir. Piyasada en çok dihidroklorit, diasetat ve diglukonat tuzları şeklinde bulunurlar. Klorheksidinin etki mekanizması; kuvvetli katyonik özelliğine dayanır. Pozitif yüklü olması nedeniyle negatif yüklü bakteri hücre duvarına, bakteriyel ekstraselüler polisakkaritlere ve hidroksiapatitlerdeki fosfat gruplarına afinite gösterir. Etkinliği pH 5.5-7 arasında en fazla, 5.2'nin altında ise oldukça düşüktür ${ }^{4,5,7-10}$.

Yüksek konsantrasyonlarda bakterisidal, düşük konsantrasyonlarda bakteriostatik etki sergiler. Düşük konsantrasyonlarda $(200 \mu \mathrm{g} / \mathrm{ml})$ pozitif yüklü klorheksidin molekülleri Gram-pozitif bakterilerde fosfat gruplarına, Gram-negatif bakterilerde yüzeydeki lipopolisakkaritlere bağlanarak bakteri hücre membranının bütünlüğünü bozar ve bakteri hücre membranının geçirgenliğini arttırır. Böylelikle bakterilerin hücresel fonksiyonları bozularak çoğalmaları engellenir. Düşük konsantrasyonlarda etkiler geri dönüşümlüdür, ortamdan klorheksidinin uzaklaşması durumunda hücre eski haline geri dönebilir. Yüksek konsantrasyonlarda ise klorheksidin bakteri hücresinin içine girerek çapraz protein bağlanması ile stoplazmanın aglutinasyonuna neden olur. Glikoziltransferaz enzimi ve fosfoenolpiruvat fosfotransferaz enzimlerini inhibe ederek geri dönüşümsüz hücre hasarına neden olur ${ }^{2,4,5,7-11}$.

Klorheksidin geniş spektrumlu antibakteriyeldir. Pek çok çalışmada pozitif kontrol grubu olarak kullanılmıştır. Özellikle Gram-pozitif bakteriler üzerinde etkilidir, Gram-negatif bakterilerde de etkinliği mevcuttur. Anaerob, aerob ve fakültatif aeroblarda yüksek etkinlik gösterir. Aktinomiçeslere, mantarlara, Enterecoccus faecalis'e karşı etkili olduğu gösterilmiştir. Pek çok sporlu bakteri, mikobakteriumlar ve virüsler ise klorheksidine karşı dirençlidir. Tıpta ve diş hekimliğinin pek çok alanında klorheksidinin antibak- teriyel etkinliğinden yararlanılmaktadır. Kavite dezenfeksiyonu da bu alanlar içinde yer alır. Çürük dokuların uzaklaştırılmasından sonra kavitede kalan rezidüel mikroorganizmaların azaltılmasında ya da eliminasyonunda başarılı olduğunu öne süren çalışmalar mevcuttur $2,4,10-12$.

Klorheksidin içerikli kavite dezenfeksiyon materyallerinin; restorasyon dolgu materyalleri yerleştirilmeden veya çeşitli sabit apareylerin (yer tutucular, ortodontik apareyler vb.) ve sabit protetik restorasyonların yapıştırılma işlemlerinin öncesinde uygulanması önerilmektedir ${ }^{8-12}$. Piyasada bulunan mevcut klorheksidin dezenfektanları arasında Klorhex (\%0.2 klorheksidin glukonat, Drogsan, Türkiye), Cavity Cleanser (\%2 Klorheksidin diglukonat, Bisco, Schaumberg), Cervitec (\%0.2 Klorheksidin diglukonat, Vivadent, Liechtenstein), Cervitec Plus (\%1 Klorheksidin diasetet, Vivadent, Liechtenstein), Consepsis Scrub (\%2 Klorheksidin glukonat, Ultradent, SJ) ve Corsodyl (\%1 Klorheksidin diglukonat, GlaxoSmithKline, ABD) örnek verilebilir ${ }^{5,6,7,10-12}$.

Farklı konsantrasyonlarda klorheksidin jellerin (\%0.12, \%0.2, \%1 ve \%2) S. mutans'a karşı antibakteriyel etkinliklerinin karşılaştırıldığı Lessa ve ark.'nın çalışmasında ${ }^{13}$ klorheksidinin antibakteriyel etkinliğinin, dozun artmasıyla istatistiksel olarak anlamlı şekilde arttığı rapor edilmiştir. Lessa ve ark.'nın ${ }^{14}$ farklı konsantrasyonlardaki klorheksidin jellerin sitotoksik etkilerini değerlendirdikleri bir başka araştırmada ise $\% 2$ 'lik klorheksidin jelin en fazla sitotoksik etki gösterdiği saptanmıştır. Bu nedenle klorheksidin güçlü bir dezenfektan olmasına rağmen epitelyal hücreler ve makrofajlar için sitotoksik olması ve dişlerde renklenmeye neden olması gibi yan etkilerinin bulunduğu unutulmamalıdır.

Klorheksidinin fiziksel ve antibakteriyel özelliklerinin geliştirilmesi amacıyla farklı maddelerle kombine edilmesi gündeme gelmiştir. Cervitec plus \%1'lik klorheksidinin diasetatın timol ile birleşimden, Cervitec jel ise \%0.2'lik klorheksidin diglukonatın sodyum florür ile birleşiminden oluşur. Cervitec Plus'un içeriğinde bulunan timol fenolden 20 kat daha etkili polifenol bileşiğidir. Hücre zarının geçirgenliğini değiştirerek bakterinin $\mathrm{pH}$ ve inorganik iyon dengesini bozmasıyla antibakteriyel özelliğini gösterir. Antibakteriyel ve antifungaldir $^{10}$. Fluoridler ise bakterilerin karbonhidrat metabolizmalarına etki ederek antibakteriyel etki göstermekte ve günümüzde dentin hassasiyetinin giderilmesi, mikrobiyal biofilmlerin kontrol altına alınması, ortodontik tedavi sonrası oluşan beyaz lezyon- 
ların önlenmesi gibi diş hekimliğinin pek çok dalında kullanılmaktadır ${ }^{9-15}$. Bu ajanların (Klorheksidin+Fluor) kombine uygulanmasının $S$. mutans ve laktobasiller üzerinde daha etkili olduğu çeşitli araştırmalar sonucunda saptanmıştır ${ }^{10,12,15}$.

\section{Sodyum Hipoklorit ( $\mathrm{NaOCl})$}

Sodyum hipoklorit kök kanal tedavilerinde en sık kullanılan antibakteriyel ajandır. Düşük konsantrasyonlarda bile bakterisid etki gösterir. Bakterilere, bakteriyofajlara, sporlara, funguslara ve virüslere karşı etkili olduğu bilinmektedir. Sodyum hipoklorit antibakteriyel etkisini direk temas ve buharlaşma yoluyla sağlamaktadır. Doku proteinlerine temas ettiğinde, peptid bağlarını kırarak proteinleri çökeltir. Ayrıca amino gruplarındaki hidrojen klor ile reaksiyona girerek antimikrobiyal etkinlikte rol oynayan kloramini oluşturur. Güçlü bir antibakteriyel ajan olmasına rağmen yüksek konsantrasyonlarda oldukça fazla toksik reaksiyon gösterir. Endotel hücre hasarı, fibroblastlara ve lenfositlere karşı toksik reaksiyonlar, submukozal hemorojiler, kollojende bazofilik dejenerasyonlar \%5.25'lik NaOCl'nin toksik etkileri arasında yer alır $5,7,16,17$.

Arisu ve ark. $^{18}$ post boşluğuna uygulanan sodyum hipoklorid, sodyum hipoklorid ve EDTA'nın birlikte kullanımı ve diyot lazerin push-out bağlanma dayanımına etkilerinin değerlendirdikleri çalışmalarında en yüksek değerleri sodyum hipoklorid ve EDTA'nın birlikte kullanıldığı grupta, en düşük değerleri ise sodyum hipokloridin kullanıldığı grupta olduğunu kaydetmişlerdir. Diyot lazer ile sodyum hipoklorid grupları arasında istatistiksel olarak anlamlı farklılık saptamamışlardır.

Sodyum hipokloritin kavite dezenfeksiyonunda kullanımı ise dentindeki kollojeni uzaklaştırdığı ve adeziv sistemlerle oluşturulan hibridizasyonu önlediği gerekçesiyle tartışmalı bir konudur ${ }^{19}$.

Arslan ve ark. ${ }^{20}$ farklı kavite dezenfektanlarının siloran bazlı rezin kompozitlerin makaslama bağlanma dayanımına etkilerini değerlendirdikleri çalışmalarında; klorheksidin, sodyum hipoklorid, propolis, ozon ve Er,Cr:YSGG lazer kullanmışlar ve sonuç olarak kontrol grubu ile kavite dezenfeksiyonu uygulanan gruplar arasında istatistiksel olarak anlamlı fark saptamamışlardır.

Ancak unutulmaması gereken bir diğer konuda $\mathrm{NaOCl}$ parçalanarak sodyum klorür ve oksijen oluşturmasıdır. Oksijen ise rezin bazlı materyallerin polimerizayonunu inhibe etmektedir. Bu durumda $\mathrm{NaOCl}^{\prime}$ nin dezavantajları arasında yer almaktadır ${ }^{19}$.

\section{Hidrojen Peroksit $\left(\mathrm{H}_{\mathbf{2}} \mathrm{O}_{\mathbf{2}}\right)$}

Bakteriler, mantarlar, sporlu mikroorganizmalar üzerine güçlü antibakteriyel özellik sergileyen $\mathrm{H}_{2} \mathrm{O}_{2}$ 'nin etkinliği oksidasyon ve köpürme özelliklerine dayanmaktadır. Oksijen ve suya kadar parçalanabilir. Özellikle katalaz aktivitesi olmayan bakteriler peroksidi çözemediği için $\mathrm{H}_{2} \mathrm{O}_{2}$ 'ye hassastır. Yapılan bazı çalışmalarda $\mathrm{H}_{2} \mathrm{O}_{2}$ 'in $S$. mutans üzerine antibakteriyel etkisinin yanı sıra; $\mathrm{H}_{2} \mathrm{O}_{2}$ 'nin özellikle çukur agar metodunda $L$. acidophilus ve $S$. aureus üzerine klorheksidin glukonattan daha fazla antibakteriyel etkinlik sergilediği de görülmüştür ${ }^{5,7,21-24}$.

Kavite dezenfeksiyonunda \%2-3'lük $\mathrm{H}_{2} \mathrm{O}_{2}{ }^{\prime}$ in pamuk pelet aracılığıyla kaviteye uygulanımı tercih edilir. ${ }^{23}$ Oksijenin rezin bazlı materyallerin polimerizasyonunu inhibe etmesi ve $\mathrm{H}_{2} \mathrm{O}_{2}$ 'in oksijen açığa çıkarması bağlantı açısından dezavantajdır ${ }^{21}$.

\section{Benzalkonyum Klorür}

Gram-pozitif bakterilerin hücre duvarlarında yer alan fosfat gruplarına, Gram-negatif bakterilerin membran polisakkaritlerine bağlanarak ve stoplazmik membranın selektif geçirgenliğini bozarak bakterisidal etki gösteren bir kuaterner amonyum bileşiğidir. Mycobacterium tuberculosis, spor oluşturan mikroorganizmalar ve virüslere karşı zayıf etki gösterir veya hiç etki göstermez. Oral mikroflora bakterilerinden $S$. mutans, $S$. salivarius, Actinomyces viscosus, $L$. acidophilus, ve $S$. aureus gibi mikroorganizmalar üzerinde güçlü bir antibakteriyel etkinliğe sahip olduğu bilinen benzalkolyum klorürün kavite dezenfeksiyonunda \%0.4-1.6'ık konsantrasyonları kullanılmaktadır. Olası yan etkisi hipersensitivite reaksiyonlarıdır ${ }^{5,7,21}$. Piyasada Tubulicid Blue ve Tubulicid Red (Suredental, Canada) adlı preperatlar bulunmaktadır ${ }^{21}$.

Say ve ark. ${ }^{25} \% 2^{\prime}$ lik klorheksidin ve $\% 1^{\prime}$ lik benzalkonyum klorür içeren dezenfektanların total etch sistemler olan One-Step ve Optibond Solo ile birlikte asitleme sonrası kullanımında, daimi diş kompozit restorasyonlarının makaslama ve gerilme dayanımına olumsuz etkisi olmadığını bildirmişlerdir.

\section{İyodin Solüsyonları}

Gram-pozitif ve Gram-negatif bakteriler üzerinde etkilidir. Funguslar, virüsler ve sporlu bakterilere oldukça zayıf etki gösterirler. Etkinliği pH, ISI, uygulama süresi ve konsantrasyona göre değişiklik gösterir. Hücre duvarına etki ederek, oksidatif yolla bakterilerin elektron transportunu bozmasıyla antibakteriyel etkisi 
medyana gelir. Moleküler iyodin antibakteriyel etkiden sorumludur, sulu çözeltileri ise stabil değildir. Bu amaçla iyodin taşıyıcı ya da iyodin salan ajanlar (iyodofor) geliştirilmiştir. En çok kullanılanlar povidon iyodin ve poloksamer iyodindir. İyodoforlar iyodin ve aktif serbest iyodin rezervuarı olarak rol oynayan taşıyıcı ya da çözücü ajan karışımından oluşur$\operatorname{lar}^{5,7,21,26}$. İyodinin de $S$. mutans, L. acidophilus ve $S$. aureus üzerine antibakteriyel etkinlik gösterdiği rapor edilmiştir $^{21}$. Piyasada bakır sülfat ve iyodin içerikli ORA-5 (Canker Sore Medicine) adlı preperat bulunmaktadır ${ }^{5}$.

\section{Fosforik Asit}

Çürük lezyonlarının uzaklaştırılması sırasında dentinde oluşan smear tabakası mikroorganizmaların barınması için uygun bir ortamdır. Bazı araştırmacılar smear tabakasının kaldırılmasında asit kullanımının kavite dezenfeksiyonu açısından önemli olduğunu savunmaktadır ${ }^{27}$.

\section{Fluorid}

Çürük proflaksisinde en sık kullanılan ajan fluoriddir. Fluorid farklı şekillerde etkinlik gösterir. Tükürük ve plakta bulunan fluorid minenin demineralize olmasını önlerken, demineralize olan minenin yapısına fosfat ve kalsiyum ile birlikte fluoridin alınması remineralizsyonu sağlar. Ayrıca bakterilerin metabolizmalarını inhibe ederek asit üretimini azalttıkları da gösterilmiştir. Fluorid bakterilerin enerji metabolizmasını etkileyerek bakterinin üremesini engeller. Ayrıca hücre zarı yapısını değişikliğe uğratarak potasyum ve fosfor dengesini bozar ve bakteri eliminasyonu sağlanabilir. Remineralizasyon ve bakterisidal etkileri göz önüne alındığında uygun yapıdaki fluoridlerin kavite dezenfektanı olarak kullanılabileceği gündeme gelmiştir $^{8,10,12}$.

Steinberg ve ark. $^{28}$ amin florür ve amin florür ile birlikte kalay florürün birlikte kullanıldığı iki farklı fluorid verniğinin antibakteriyel özelliklerini değerlendirmişler ve her iki verniğinde güçlü antibakteriyel özellikleri bulunduğunu bildirmişlerdir.

\section{Propolis}

Günümüzde doğal ürünlere olan ilgilinin giderek artması sağlık sektöründe de bu ürünlerin araştırılmasına neden olmaktadır. Diş hekimliğinde de araştırmalara konu olan propolis; antimikrobiyal, antiviral, antienflamatuar, rejeneratif, antihepatotoksik, immunmodulatör, antioksidan, antimutajenik ve karsinostatik özelliklere sahiptir. Propolisi işçi arılar kovanlarının içini dezenfekte etmek için bitkilerin filiz ve tomurcuklarından topladıkları reçinemsi madde ile oluştururlar. İçeriğinde vitaminler, mineral tuzlar, flavonoidler, yağ asitleri, aromatik asitler, esterler ve henüz tanımlanamamış maddeler yer alır. $S$. mutans, $S$. sobrinus ve Candida Albicans ( $C$. albicans) gibi çürük oluşumunda etkili olan mikroorganizmalar üzerinde güçlü antimikrobiyal etkinlik gösterir ${ }^{29}$.

Arslan ve ark. ${ }^{20}$ yaptıkları çalışmada farklı kavite dezenfektanlarının siloran bazlı rezin kompozitlerin makaslama bağlanma dayanımına etkilerini incelemişlerdir. Propolisin kavite dezenfeksiyonu olarak uygulandığı grup ile kontrol grubu arasında istatistiksel olarak anlamlı fark saptanmamıştır.

Arslan ve ark. ${ }^{6}$ yaptıkları bir diğer çalışmada da; $\mathrm{Er}, \mathrm{Cr}$ :YSGG lazer, klorheksidin, propolis ve ozonun kavite dezenfeksiyonu amacıyla uygulanımında etchand-rinse sistem ile yapılan kompozit restorasyonların mikrosızıntı değerleri arasında istatistiksel olarak anlamlı fark saptamadıklarını bildirmişlerdir.

\section{Aloe Vera}

Aloe vera, kuru sıcak iklimlerde yetişen Liliaceae ailesine mensup kaktüs benzeri bir bitkidir. Yapraklarının merkezinde bulunan muköz doku aleosin, aloin, metilkromon, flavonoidler, steroidler, vitaminler, aminoasitler gibi 75 farklı aktif maddeyi içerir. Antienflamatuar, antibakteriyel, antioksidan etkinliği gösterilmiştir. Çürük ile ilişkili bakterilere karşı antimikrobiyal etkinlik gösterdiği bildirilmiştir. Restorasyonların fiziksel özelliklerine olan etkilerini araştıran az miktarda yayın bulunmaktadır ${ }^{30}$.

Fosforik asit, Corsodyl ve Cervitec jel ile aloe vera içerikli Forever Bright ve Gengigel'in $S$. mutans'a karşı antibakteriyel etkinliğinin disk difüzyon yöntemi ile değerlendirildiği Tüzüner ve ark. ${ }^{12}$ çalışmalarında tüm jeller $S$. mutans'a karşı antibakteriyel etkinlik göstermiştir.

\section{Ozon}

Ozon, oksijen atomunun farklı bir formudur. Doğada güneşten gelen mor ötesi ışınların (UV) atmosferdeki oksijeni parçalamasıyla oluşur. Kliniklerde kullanılan sistemlerde ise parçalama işlemi için ozon jeneratörü kullanılır. Güçlü antibakteriyel, antifungal ve antiviral etki gösterir. Ozon hücre duvarlarında yıkıma neden olur. Ayrıca glikoproteinler, glikolipidler ve aminoasitleri etkileyerek enzimatik sistemleri bloke eder. Böylelikle membran geçirgenliği artar. Ozon molekülleri hızlıca hücreye girerek mikroorganizmaların ölümüne neden olur. Diş çürüğü oluşumunda etkili 
olan S. mutans, S. sobrinus ve Laktobasil sayılarında 10 veya 20 sn ozon uygulanması ile \%99 azalma gözlenmiştir. ${ }^{31}$ Ayrıca yapılan bazı çalışmalarda tükürük varlığında 10 ve 30 sn ozon uygulamasının $S$. mutans ve $L$. Casei sayılarını azaltamadığı, ancak uygulama süresi 60 sn' ye kadar çıkarıldığında tükürük proteinlerinin değişime uğratarak mikroorganizmaların azaltılmasında etkili olduğu da gösterilmiştir ${ }^{32,33}$.

Ozon gazının dezenfeksiyon sonrasında herhangi bir artık veya kalıntı bırakmaması avantajları arasındadı $^{31,34}$. Schmidlin ve $\operatorname{ark}^{35} 60$ sn ve Cadenaro ve $\operatorname{ark}^{36} 80$ sn ozon uygulamasının self etch adeziv sistemlerin mine ve dentine olan bağlanma dayanımını etkilemediğini bildirmişlerdir. Magni ve ark ${ }^{37} 120$ sn' lik ozon uygulamasının test ettikleri adezivlerin mekanik özelliklerini etkilemediğini rapor etmiş ve ozonun, kavite dezenfektanı olarak kullanılabileceğini ileri sürmüşlerdir.

Piyasada en sık kullanılan ozon sistemleri HealOzone (Kavo, Germany) ve OzonyTron (Mymed, Germany)' tir. HealOzone sisteminde bulunan steril edilebilen el aleti ve bağlantı tüpü ile ağız ortamına kolayca erişim sağlanmaktadır. El aletinin ucuna yerleştirilen dişi tamamen kavrayabilecek sızdırmaz silikon başık ile ozon gazı dişe uygulanır. Herhangi bir sızdırma durumunda sistem çalışmaz. Uygulama sonunda silikon başlıktaki ozon tekrar toplanarak oksijene dönüştürülür. OzonyTron sisteminde ise farklı boyutlarda cam problar bulunur. Kullanilan ozon konsantrasyonu $\quad 10-100 \quad \mu \mathrm{g} / \mathrm{ml}$ arasında değişebilmektedir ${ }^{31}$.

\section{Işıkla Aktive Olan Dezenfeksiyon Sistemleri [Light-Activated -Disinfection (PAD)]}

Işıkla aktive olan dezenfeksiyon sistemi; fotodinamik terapi ya da fotodinamik antimikrobiyal terapi olarak da adlandırılır. Işığa duyarı bir maddenin uygun bir ışık kaynağı ile aktive edilmesi prensibine dayalı bir sistemdir. Etki mekanizması; ışığa duyarlı ajanda bulunan ışığa hassas moleküller bakteri duvarına bağlanır. Bu moleküllerin absorbe edebileceği dalga boyunda ışık uygulanır. Işıktan absorbe ettiği enerji ile oksijeni; oksijen iyonları ve radikalleri gibi reaktif oksijen artıklarına dönüştürür. Reaktif oksijen artıkları hızlı ve güçlü bir şekilde bakteri membranını ve DNA'sını parçalayarak hücre ölümüne neden olur. Etkinliği sadece bakterilerle sınırlı olmayıp virüsler, protozoalar ve mantarlar gibi pek çok mikroorganizma üzerinde de etkilidir. Işıkla aktive olan dezenfeksiyon sisteminin antimikrobiyal ajanlara dirençli olan mikroorganizmalara karşı alternatif bir tedavi seçeneği olabileceği de düşünülmektedir. Ayrıca mikroorganizmaların LAD ile oluşan reaktif oksijen artıklarına karşı direnç geliştirmeleri olası gözükmemektedir. Bu nedenle tekrarlanan uygulamalarla dirençli suşların gelişmesi mümkün değildir ${ }^{38,39}$.

Fotodinamik terapi özellikle kanser tedavileri olmak üzere tıbbın çeşitli dallarında kullanılmaktadır. Dişhekimliğinde kullanımı ise; oral kanserlerin ve ağız içi bakteriyel ve fungal enfeksiyonların tedavisinde, endodontik tedavilerde ve kavite dezenfeksiyonunda görülmektedir. Fotodinamik reaksiyonun gerçekleşmesi için ışığa duyarlı ajana, ışık kaynağına ve oksijene intiyaç duyulur. Işığa duyarlı ajanın sadece lokal toksisite göstermesi gerekir. Işıkla aktive olan dezenfeksiyon sisteminde kullanılan ajanlar;

- Fenotiazin türevi boyalar [Metilen mavisi (MB) ve Toluidin mavisi O (TBO; tolonium chloride)]

- Fitalosiyaninler [aluminum disulphonated phthalocyanine ve katyonik Zn(II)-phthalocyanine]

- Klorinler [chlorin e6, Sn (IV) chlorin e6, chlorin e62.5 Nmethyl-d-glucamine (BLC1010)]

- Porfirinler (hematoporphyrin $\mathrm{HCl}$, Photofrin ${ }^{\circ}$, ve ALA)

- Xanthene (erythrosin)

- Monoterpene (azulene)' $\mathrm{dir}^{38}$.

Nötral veya anyonik yapıdaki ışığa duyarlı ajanlar Gram-pozitif bakterilere etkin bir şekilde bağlanabilirken, Gram-negatif bakterilere etkin olarak bağlanamazlar. Gram-negatif bakterilerde etkinliğin sağlanması için bu ajanlara katyonik bir molekülün eklenmesi gerekir ${ }^{39}$.

Işıkla aktive olan dezenfeksiyon sistemlerinde özel dalga boyunda, düşük kuvvette ve görülebilir ışık üreten kaynak gereklidir. Bu amaçla kullanılan ilk ışık kaynakları argon, KTP ve Nd:YAG lazerlerdir. Bu kaynakların kompleks ve pahalı olması yeni arayışlara neden olmuştur. Günümüzde ışıkla aktive olan dezenfeksiyon sistemlerinin büyük bir çoğunluğunda uzun dalga boyu ve derin ışık penetrasyonu sağlayan 630$700 \mathrm{~nm}$ dalga boyunda kırmızı ışıklar kullanılmaktadır $^{38-40}$.

Zanin ve ark. ${ }^{41}$ çalışmalarında dana dişlerinden elde edilen mine diskleri üzerinde oluşturulan $S$. mutans, $S$. sobrinus ve $S$. sangius biofimlerinde LED ve toluidin mavisinin etkinliği araştırılmıştır. $S$. mutans ve $S$. sobrinus biofilmlerindeki canlı hücre sayısında yaklaşık olarak \%95 azalma gözlenirken, $S$. sangius biofilminde \%99.9'dan daha fazla azalma gözlenmiştir. Aynı araştırmacının toluidin mavisinin LED ve Helyum/ Neon lazer ile aktive edilmesiyle $S$. mutans biofilmi üzerinde oluşan antimikrobyal etkinliğini değerlendir- 
diği çalışmasında \%99.9'a varan canlı hücre sayısında azalma gözlenirken iki ışık kaynağı arasında anlamlı fark görülmemiştir.

Longo ve ark. ${ }^{42}$ çürük dokunun fotodinamik terapi ile dezenfeksiyonunun in vitro ve in vivo koşullarda değerlendirmişlerdir. Çalışmada ışığa duyarlı ajan olarak Alüminyum-klorit-pitalosiyonin ışık kaynağı olarak da $660 \mathrm{~nm}$ dalga boyunda kırmızı lazer ışığı kullanıımışır. Çalışmanın in vivo kısmında sınıf I çürük lezyonları bulunan yetişkin ve çocuk 10 hastada fotodinamik terapinin etkinliği değerlendirilmiştir. Hastaların çürük dentinleri ART yöntemiyle sert dentine gelene kadar uzaklaştırımışır. Kavitelerin mezial kısmından dentin örneği alınmıştır. Daha sonra fotodinamik terapi uygulanmış ve distal kısmından dentin örneği alınmıştır. Örnekler BHI içeren besi yerlerine ekilmiştir. Çalışmanın sonuçlarına göre fotodinamik terapinin sitotoksik etkisi bulunmazken, bakteri sayısında \%82 oranında azalma gözlenmiştir.

\section{Lazer}

LASER 'Light Amplification by Stimülated Emission of Radiation' kelimelerinin baş harflerinden oluşmakta ve 'Radyasyonun uyarılmış emisyonu ile ışığın güçlendirilmesi' anlamına gelmektedir. Daha açık bir ifadeyle 'hızlandırılmış ve yoğunlaştırılmış yüksek enerji taşıyan ışık demeti' anlamını taşımaktadır. Türkçe telafuzuna uyumu sebebiyle 'Lazer' kelimesi kullanılmaktadır ${ }^{43}$.

Lazer ışını teorisinin temeli $1916^{\prime}$ da Albert Einstein tarafından sunulan 'Kuantum Teorisine' dayanır. Einstein maddelerin durgun bir yapısının olmadığını, elementer parçacıklarının sürekli hareket halinde olduğunu ve uygun boyuttaki bir foton uyarılmış bir moleküle çarparsa başka bir foton yayabileceğini öne sürmüştür. Bu teoriden yola çıkarak 1951 yılında Charles Hard Townes uyarılmış salınım prensibiyle çalışan 'MASER' i (Microwave Amplification of Stimulated Emission of Radiation) keşfetmiştir. İlk lazer cihazı 1960 yılında yakut lazer 'Ruby' adıyla Theodore Maiman tarafından tanıtılmıştır ${ }^{6,43,44}$.

Yakut lazer dişhekimliğinde araştırmalara konu olmuş fakat çevre dokularda mekanik ve termal hasarlara yol açmıştır. Neodymiyum: Yittriyum Alüminyum Garnet (Nd:YAG) ve Karbondioksit $\left(\mathrm{CO}_{2}\right)$ lazerler Food and Drug Administration (FDA) tarafından ağız içi uygulamaya onay verilen ilk lazerlerdir. Oldukça yüksek güçte çalışan bu lazerler yumuşak dokuda kesme ve koagülasyonda başarılı olmasına rağmen sert dokular üzerinde etkinliğinin düşük olması ve olumsuz termal etkileri nedeniyle sert dokularda kullanımları kısıtlanmıştır. Erbiyum grubu lazerlerin Zharikov tarafından keşfi ile düşük enerjide diş sert dokularında çevre dokularda hasar oluşturmadan preperasyonlar gerçekleştirilmiştir. Bakterisit etkileri, anestezi ihtiyacını azaltmaları gibi avantajları bulunan erbiyum grubu lazerler 1997 yılında FDA tarafından onaylanmıştır. Günümüzde diş hekimliğinin her dalında çeşitli lazer tipleri kullanılmakta ve araştırmalara devam edilmektedir $^{44-46}$.

Diş hekimliğinde sıklıkla kullanılan lazerler Argon, Diyot, $\mathrm{CO}_{2}$, Nd:YAG, Erbiyum Kromiyum: Yttrium Alüminyum Garnet (Er:YAG), Erbiyum Kromiyum: Yittriyum Skandiyum Galyum Garnet (Er,Cr:YSGG) lazelerdir $^{44-49}$.

$\mathrm{Er}, \mathrm{Cr}$ :YSGG lazerler ile hazırlanan kavite preperasyonlarında geleneksel aeratör kullanımına göre daha az basınç ve titreşim meydana gelir. Ayrıca ısı ve mekanik etkinin oluşmaması anesteziye ihtiyaç duyulmaksızın tedavinin tamamlanmasına olanak sağlar. Bu nedenle korku ve endişenin kontrol edilebilmesi en önemli avantajları arasında yer alır. Ayrıca erbiyum grubu lazerlerin dalga boyları bakteri hücrelerinin su içeriği tarafından da absorbe edilerek bakterisidal etki gösterir. Kavite dezenfeksiyonunda ve kök kanal tedavisinde bu bakterisidal etkiden fayda lanilır. Sistemin diğer avantajları arasında ise uygulandığı bölgede pürüzlendirme sağlaması, diş yüzeyinde Ca ve P miktarını arttırarak asit ataklarına karşı daha dirençli doku oluşturması yer alır. Yapılan çalışmalarda $\mathrm{Er}, \mathrm{Cr}$ : YSGG lazerin özellikle S.mutans üzerinde etkili olduğu görülmüştür. Kimyasal dezenfektanlar en fazla $130 \mu \mathrm{m}$ derinliğe penetre olabilirken, lazer irradiasyonları ile 500-1000 $\mu \mathrm{m}$ derinliğe kadar penetrasyon sağlanması lazer sistemleri ile kavite dezenfeksiyonunun en önemli avantajları arasındadır. Ayrıca kimyasal dezenfektan kullanımında karşılaşılan mikrosızıntı ve bağlanma sorunları lazer irradiasyonu dezenfeksiyonunda gerçekleşmediği bildirilmiştir ${ }^{44-48}$.

Yumuşak lazerler arasında yer alan diyot lazerler; sert lazerler gibi yüksek güce sahip olmamasına rağmen, yüksek elektrik ve optik etkinlikliği ve düşük maliyetleri nedeniyle diş hekimleğinde tercih edilen lazerler arasında yer alır. Diyot lazer cihazından yayılan ışının bir miktarı en uç kısımda ısıya dönüşerek 'hot tip' sıcak uç denilen durumu oluşturur. Bu özelliği ile uygulandığı dokuda koagülasyon ve buharlaşma meydana getirir. Dişhekimliğinde diyot lazer yaygın olarak diş beyazlatma, yumuşak doku cerrahisi, melanin pigmentasyonunun giderilmesi ve düşük seviyeli lazer terapisinde kullanılır. Son dönemde antimikrobiyal etkinliği nedeniyle endodontik tedavilerde 
ve kavite dezenfeksiyonunda sıkça kullanılmaya başlanmıştır ${ }^{49}$.

Yüksek güçlü lazer ışığı çürüğe etki eden mikroorganizmalara ve inflamatuar dental hastalıklarda etkili olduğu bilinen bakterisidal özelliğe sahiptir. Farklı mikroorganizmalara karşı değişik lazer tiplerinin antibakteriyel etkinliğinin değerlendirildiği araştırmalar literatürde mevcuttur ${ }^{49-51}$.

Mehrvarzfar ve ark. ${ }^{52} \% 2.5$ sodyum hipoklorit, $\% 2$ klorheksidin ve MTAD'ın ayrıca bu iriganların 2W diod lazerin 5 sn uygulama 15 sn bekleme şeklinde beş sefer uygulanımı ile birlikte kullanımının Enterococcus Faecalis (E. faecalis)'e karşı antibakteriyel etkinliğini inceledikleri çalışmalarında MTAD (doksisiklin, sitrik asit ve deterjan) ile diod lazerin birlikte kullanıldığı grupta tüm bakteriler elimine edilmiştir.

Basso ve ark. $^{53}$ düşük seviyeli lazer terapisinin tipik oral mikrobiyal filmlere etkisini in vitro koşullarda incelemişlerdir. Çalışmada sadece $S$. mutans'dan oluşan biofilm, sadece $C$. Albicans'dan oluşan biofilm ve iki mikroorganizmanın oluşturduğu biofilme 5,10 ve $20 \mathrm{~J} / \mathrm{cm}^{2}$ diod lazer uygulanmıştır. İrradiasyondan sonra biofilmin canlıı̆ı MTT analizi ile, biofilmin gelişimi cfu/ml cinsinden, hücre morfolojileri ise SEM cihazı ile incelenmiştir. Sadece S.mutans'ın bulunduğu biofilm tüm lazer dozlarına benzer cevap vermiştir. $C$. albicans ile $S$. mutans'ın birlikte oluşturduğu biofilmde ise doz arttıkça canlı mikroorganizma sayısı azalmıştır. Çalışmanın sonucunda düşük dozlu lazer terapisinin mikroorganizmlar üzerinde inhibe edici etkisinin bulunduğu fakat bu etkinin farklı mikrobiyal örneklerin birbirleri ile ilişkisiyle farklııklar gösterebileceği belirtilmiştir.

Türkün ve ark. ${ }^{54}$ çalışmalarında $0.75 \mathrm{~W}$ ve $1 \mathrm{~W}$ Er,Cr:YSGG lazer ve \%2 klorheksidin içerikli Corsodyl'in kavite dezenfeksiyonunda $S$. mutans'a karşı etkinliğini dana dişi modeli ile değerlendirmişlerdir. Lazer irradiasyonu 5 sn uygulama 15 sn dinlenme şeklinde 5 period halinde uygulanmıştır. Tüm gruplar $S$. mutans'a karşı anlamlı olarak etkin bulunmuştur. Gruplar arasında en etkin 1W Er,Cr:YSGG grubu olmasına rağmen istatistiksel olarak anlamlı bulunmamıştır.

Farklı dentin kalınlıklarına (500, 1000 ve 2000 $\mu \mathrm{m})$ uygulanan $0.5,1,3,5$ ve $7 \mathrm{~W}$ gücündeki diyot lazerin $S$. mutans' a karşı antibakteriyel etkinliğinin değerlendirildiği Lee ve ark. ${ }^{55}$ çalışmasında $500 \mu \mathrm{m}$ kalınlıktaki dentinde $0.5,1,3,5$ ve $7 \mathrm{~W}$ gücündeki diod lazerin $S$. mutans eliminasyonu sırasıyla \%19.4, 32.5, 56.8, 90.8 ve 97.7 olarak bulunmuştur. İstatis-

tiksel olarak 0.5 ile $1 \mathrm{~W}$ ve 5 ile $7 \mathrm{~W}$ arasında fark bulunamamıştır. Diod lazerin 1000 ve $2000 \mu \mathrm{m}$ kalınlığındaki dentine 7W gücünde uygulandığında eliminasyonu sırasıyla \%50.9 ve \%20.1 bulunmuştur ve istatistiksel olarak anlamlı görülmüştür.

İpek Arslan: ORCID ID: 0000-0002-8648-3554

Özgül Baygın: ORCID ID: 0000-0003-0836-7619

\section{KAYNAKLAR}

1. Maupome G, Hernandez-Guerrero JC, Garcia-Luna M, Trejo-Alvarado A, Hernandez-Perez M, Diez-deBonilla J. In vivo diagnostic assessment of dentinal caries utilizing acid red and povidone-iodine dyes. Oper Dent 1995;20:119-22.

2. Ersin NK, Candan U, Aykut A, Eronat C, Belli S. No adverse effect to bonding following caries disinfection with chlorhexidine. J Dent Child (Chic) 2009;76:20-7.

3. Boston DW, Graver HT. Histobacteriological analysis of acid red dye-stainable dentin found beneath intact amalgam restorations. Oper Dent 1994;19:65-9.

4. van Strijp AJ, van Steenbergen TJ, ten Cate JM. Effects of chlorhexidine on the bacterial colonization and degradation of dentin and completely demineralized dentin in situ. Eur J Oral Sci 1997;105:27-35.

5. McDonnell G, Russell AD. Antiseptics and disinfectants: activity, action, and resistance. Clin Microbiol Rev 1999;12:147-79.

6. Arslan S, Yazici AR, Gorucu J, Pala K, Antonson DE, Antonson SA. Comparison of the effects of Er,Cr:YSGG laser and different cavity disinfection agents on microleakage of current adhesives. Lasers Med Sci 2012;27:805-11.

7. Bin-Shuwaish MS. Effects and effectiveness of cavity disinfectants in operative dentistry: A literature review. J Contemp Dent Pract 2016;17: 867-79.

8. Hamilton IR. Biochemical effects of fluoride on oral bacteria. J Dent Res 1990;69:660-7.

9. Mohan PV, Uloopi KS, Vinay C, Rao RC. In vivo comparison of cavity disinfection efficacy with APF gel, Propolis, Diode Laser, and 2\% chlorhexidine in primary teeth. Contemp Clin Dent 2016; 7: 45-50.

10. Erdem AP, Sepet E, Kulekci G, Trosola SC, Guven $Y$. Effects of two fluoride varnishes and one fluoride/chlorhexidine varnish on streptococcus mutans and streptococcus sobrinus biofilm formation in vitro. Inter J of Medil Sci 2012;9: 12936. 
11. Subramaniam $P$, Naidu P. Effect of tooth mousse plus and cervitec gel on S. mutans. J Minim Interv Dent 2009;2:164-169

12. Tuzuner T, Ulusoy AT, Baygin O, Yahyaoglu G, Yalcin I, Buruk K. Direct and transdentinal (Indirect) antibacterial activity of commercially available dental gel formulations against streptococcus mutans. Med Princ Pract 2013;3:1-5.

13. Lessa FC, Nogueira I, Vargas Fda S, Spolidorio DM, Hebling J, Garcia-Godoy F. Direct and transdentinal antibacterial activity of chlorhexidine. Am J Dent 2010;23:255-9.

14. Lessa FC, Nogueira I, Huck C, Hebling J, Costa CA. Transdentinal cytotoxic effects of different concentrations of chlorhexidine gel applied on acid-conditioned dentin substrate. J Biomed Mater Res B Appl Biomater 2010;92:40-7.

15. Baygin O, Tuzuner T, Ozel MB, Bostanoglu O. Comparison of combined application treatment with one-visit varnish treatments in an orthodontic population. Med Oral Patol Oral Cir Bucal 2013;18: 362-70.

16. Peker DÖB. Sodyum hipokloritin fikse ve fikse olmayan insan pulpa dokularını çözücü etkisi. HÜ Dis Hek Fak Derg 1993;21:21-3.

17. Pioch $T$, Kobaslija S, Schagen B, Gotz $H$. Interfacial micromorphology and tensile bond strength of dentin bonding systems after $\mathrm{NaOCl}$ treatment. J Adhes Dent 1999;1:135-42.

18. Arisu HD, Kivanc BH, Saglam BC, Simsek E, Gorgul G. Effect of post-space treatments on the push-out bond strength and failure modes of glass fibre posts. Aust Endod J 2013;39:19-24.

19. Berber VB, Gomes BP, Sena NT, Vianna ME, Ferraz CC, Zaia AA. Efficacy of various concentrations of $\mathrm{NaOCl}$ and instrumentation techniques in reducing Enterococcus faecalis within root canals and dentinal tubules. Int Endod J 2006; 39:10-7.

20. Arslan S, Yazici AR, Gorucu J, Ertan A, Pala K, Ustun $Y$. Effects of different cavity disinfectants on shear bond strength of a silorane-based resin composite. J Contemp Dent Pract 2011;12:279-86.

21. Turkun M, Turkun LS, Ergucu Z, Ates M. Is an antibacterial adhesive system more effective than cavity disinfectants? Am J Dent 2006;19:166-70.

22. Özel E, Yurdagüven H, Say EC, Kocagöz S. Fosforik asit ve dezenfektan solüsyonların streptococcus mutans'a karşı antibakteriyel etkisinin saptanması. HÜ Diş Hek Fak Derg 2005;29:8-14.
23. Türkün $M$, Türkün LS, Ateş $M$. Antibacterial activity of cavity disinfectants. Balk J Stom 2004;8:214-9.

24. Ohara P, Torabinejad M, Kettering JD. Antibacterial effects of various endodontic medicaments on selected anaerobic bacteria. J Endod 1993;19: 498-500.

25. Say EC KF, Tarım B, Soyman M, Gülmez T. In vitro effect of cavity disinfectants on the bond strength of dentin bonding systems. Quintessence Int 2004;35:56-60.

26. Gultz J, Do L, Boylan R, Kaim J, Scherer W. Antimicrobial activity of cavity disinfectants. Gen Dent 1999;47:187-90.

27. Ersöz EÖP. The effect of various acids in different concentrations on the dentin surface, a SEM study. Türkiye Klin Diş Hek Bil Derg 1999;5:55-9.

28. Steinberg D, Rozen R, Klausner EA, Zachs B, Friedman $M$. Formulation, development and characterization of sustained release varnishes containing amine and stannous fluorides. Caries Res 2002;36:411-6.

29. Özan Ü Hİ, Sümer Z. Sodyum hipoklorit, klorheksidin ve propolis içerikli solüsyonların Potasyum Titanyum Fosfat Lazer ile birlikte kullanımlarının Candida Albicans üzerine etkilerinin incelenmesi. Cumhuriyet Üniv Dişhek Fak Derg 2009;12:33-8.

30. Ndhlala AR, Amoo SO, Stafford GI, Finnie JF, Van Staden J. Antimicrobial, anti-inflammatory and mutagenic investigation of the South African tree aloe (Aloe barberae). J Ethnopharmacol 2009; 124:404-8.

31. Azarpazhooh A, Limeback $H$. The application of ozone in dentistry: a systematic review of literature. J Dent 2008;36:104-16.

32. Knight GM, McIntyre JM, Craig GG, Mulyani, Zilm PS. The inability of Streptococcus mutans and Lactobacillus acidophilus to form a biofilm in vitro on dentine pretreated with ozone. Aust Dent J 2008;53:349-53.

33. Johansson $E$, Claesson $R$, van Dijken JW. Antibacterial effect of ozone on cariogenic bacterial species. J Dent 2009;37:449-53.

34. Dinç G. Kavite dezenfektanlarının antibakteriyel özellikleri, bağlanma dayanımı ve mikrosızıntı üzerine etkileri. Atatürk Üniv Diş Hek Fak Derg 2012;6;66-75.

35. Schmidlin PR, Zimmermann J, Bindl A. Effect of ozone on enamel and dentin bond strength. J Adhes Dent 2005;7:29-32. 
36. Cadenaro M, Delise C, Antoniollo F, Navarra OC, Di Lenarda R, Breschi L. Enamel and dentin bond strength following gaseous ozone application. J Adhes Dent 2009;11:287-92.

37. Magni E, Ferrari M, Hickel R, Huth KC, Ilie N. Effect of ozone gas application on the mechanical properties of dental adhesives bonded to dentin. Dent Mater 2008;24:1428-34.

38. Konopka K, Goslinski T. Photodynamic therapy in dentistry. J Dent Res 2007;86:694-707.

39. Komerik N, MacRobert AJ. Photodynamic therapy as an alternative antimicrobial modality for oral infections. J Environ Pathol Toxicol Oncol 2006; 25:487-504.

40. Kubler A, Niziol C, Sidhu M, Dunne A, Werner JA. Analysis of cost effectiveness of photodynamic therapy with Foscan (Foscan-PDT) in comparison with palliative chemotherapy in patients with advanced head-neck tumors in Germany. LaryngoRhino-Otologie 2005;84:725-32.

41. Zanin IC, Lobo MM, Rodrigues LK, Pimenta LA, Hofling JF, Goncalves RB Photosensitization of in vitro biofilms by toluidine blue $\mathrm{O}$ combined with a light-emitting diode. Eur J Oral Sci 2006;114:64-9.

42. Longo JP, Leal SC, Simioni AR, de Fatima Menezes Almeida-Santos M, Tedesco AC, Azevedo RB. Photodynamic therapy disinfection of carious tissue mediated by aluminum-chloride-phthalocyanine entrapped in cationic liposomes: an in vitro and clinical study. Lasers Med Sci 2012;27:575-84.

43. Goldman L, Gray JA, Goldman J, Goldman B, Meyer R. Effect of Laser Beam Impacts on Teeth. J Am Dent Assoc 1965;70:601-6.

44. Uysal D, Güler Ç. Diş hekimliğinde lazer: bir literatür derlemesi. Atatürk Üniv Diş Hek Fak Derg 2012;6:44-53.

45. Bader C, Krejci I. Indications and limitations of Er:YAG laser applications in dentistry. Am J Dent 2006;9:178-86.

46. Whitters CJ, Strang R. Preliminary investigation of a novel carbon dioxide laser for applications in dentistry. Lasers Surg Med 2000;26:262-9.

47. Usumez A, Aykent F. Bond strengths of porcelain laminate veneers to tooth surfaces prepared with acid and Er,Cr:YSGG laser etching. J Prosthet Dent 2003;90:24-30.

48. Coluzzi DJ. An overview of laser wavelengths used in dentistry. Dent Clin North Am 2000; 44: 753-65.
49. Milliard MJ ML, Aronoff BL, Hults D. Soft tissue studies with $805 \mathrm{~nm}$ Diode laser radiation: Thermal effects with contact tips and comparison with 1064 nm Nd:YAG laser radiation. Lasers Surg Med 1993; 13: 528-36.

50. Prabhakar AR, Karuna YM, Yavagal C, Deepak BM. Cavity disinfection in minimally invasive dentistry comparative evaluation of Aloe vera and propolis: A randomized clinical trial. Contemp Clin Dent 2015;6:S24-31.

51. Sulieman M. An overview of the use of lasers in general dental practice: 1 . Laser physics and tissue interactions. Dent Update 2005;32:228-330.

52. Mehrvarzfar $P$, Saghiri MA, Asatourian A, Fekrazad R, Karamifar K, Eslami G. Additive effect of a diode laser on the antibacterial activity of $2.5 \% \mathrm{NaOCl}, 2 \% \mathrm{CHX}$ and MTAD against Enterococcus faecalis contaminating root canals: an in vitro study. J Oral Sci 2011;53:355-60.

53. Basso FG, Oliveira CF, Fontana A, Kurachi C, Bagnato VS, Spolidorio DM In Vitro effect of lowlevel laser therapy on typical oral microbial biofilms. Braz Dent J 2011;22:502-10.

54. Turkun $M$, Turkun LS, Celik EU, Ates $M$. Bactericidal effect of $\mathrm{Er}, \mathrm{Cr}$ :YSGG laser on Streptococcus mutans. Dent Mater J 2006;25:81-6.

55. Lee BS, Lin YW, Chia JS, Hsieh TT, Chen MH, Lin CP. Bactericidal effects of diode laser on Streptococcus mutans after irradiation through different thickness of dentin. Lasers Surg Med 2006;38:62-9.

\author{
Yazışma Adresi \\ Doç.Dr.Özgül BAYGIN \\ Karadeniz Teknik Üniversitesi Diş Hekimliği \\ fakültesi Pedodonti Anabilim Dalı, \\ 61080,Trabzon / Türkiye \\ GSM: 05327607660 \\ E-mail: dtozgul@gmail.com
}

